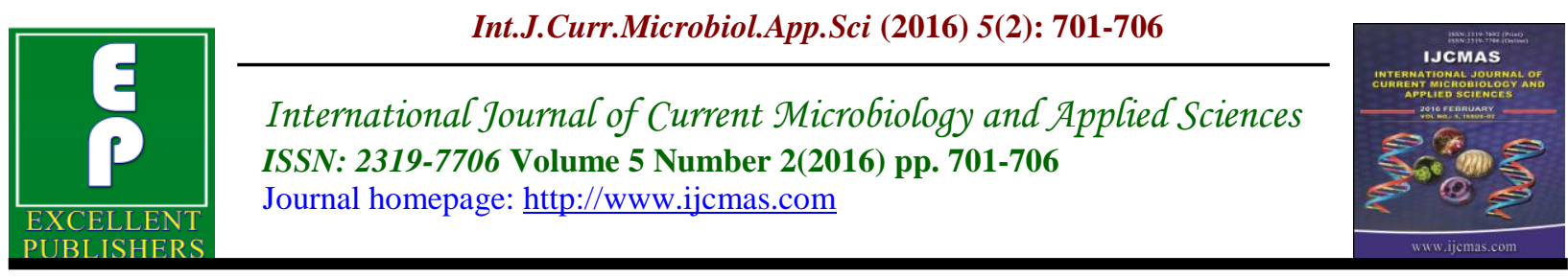

Original Research Article

doi: http://dx.doi.org/10.20546/ijcmas.2016.502.xxx

\title{
Effect of Azadirachta indica Leaf extract on protein content in muscles and gills of semi fingerling of Catla catla
}

\author{
Rukhsar Shaikh*, M.A.Majid and KalimShaikh \\ Department of Zoology, AKI'S Poona College of Arts, Commerce and Science Camp, \\ Pune-411001, India \\ *Corresponding author
}

\begin{tabular}{|c|c|}
\hline \multirow[b]{3}{*}{ Keywords } & A B S T R A C T \\
\hline & \multirow{13}{*}{ 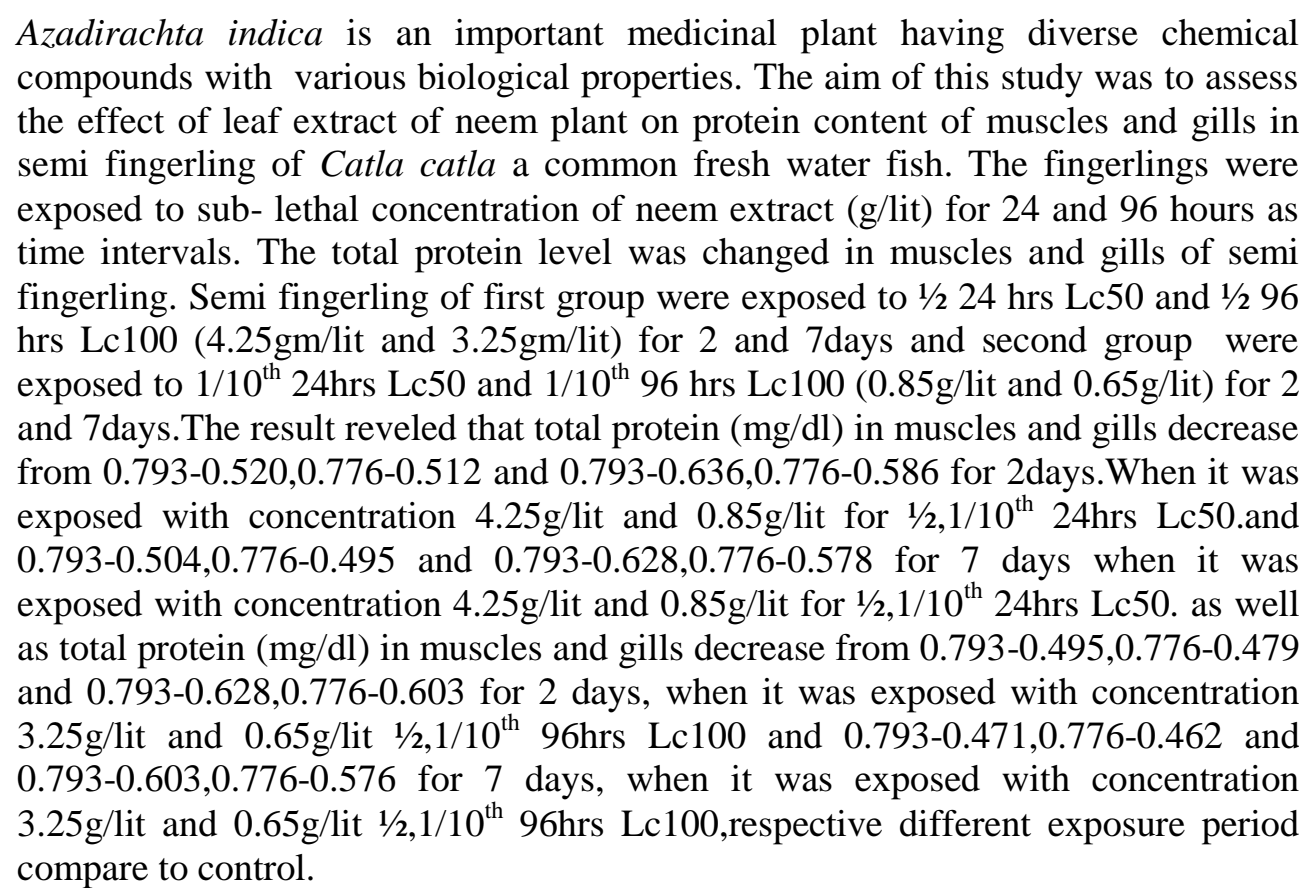 } \\
\hline & \\
\hline $\begin{array}{l}\text { Azadirachta } \\
\text { indica, }\end{array}$ & \\
\hline Semi fingerling, & \\
\hline & \\
\hline Gills, & \\
\hline Protein & \\
\hline Article Info & \\
\hline & \\
\hline Available Online: & \\
\hline & \\
\hline & \\
\hline & \\
\hline
\end{tabular}

\section{Introduction}

Azadirachta indica is one of the most promising medicinal plant having a wide spectrum of biological activity and well known for its insecticidal properties (ICAR, 1993). Every part of neem tree have been known to possess a wide range of pharmacological properties, especially as antibacterial, antifungal, antiulcer, antifeedant, repellent, pesticidal, mollus- cicidal, ecdysome inhibitor and sterilant is commercially exploitable (Biswas et al., 2002; Das et al., 2002) and hence traditionally used to treat large number of disease (Van Der Nat et al., 1991).

Both fish parasites and fish predators which cause great economic losses in productivity are mainly controlled with toxic chemicals, 
mostly applied indiscriminately and without adequate training (Senhorini, 1991).Thus use of pesticides in aquaculture system to control fish disease, parasites and other pests not only leads to high level of residues in animals but also may interfere with the maintenance of their homeostasis and thus affect their performance (Barton and Iwama,1991; Wendelaar Bonga,1997). In view of the environmental problems caused by the use of synthetic chemicals and the growing need for alternative method of pest control that minimize this damage, there has been extensive research on pest control by substance from plant (Wan et al., 1996). One of the most promising compound is Azadirachtin (AZA) an active compound extracted from the Azadirachta indica, its antiviral, antibacterial and antifungal properties have been known for several year (Harikrishnan, et al., 2003). The chemistry and biological activity of both neem extract and purified AZA have been investigated in various countries (Biswas, et al., 2002).

Azadirachta indica has been used successfully in aquaculture system to control fish predators (Dunkel and Ricilards, 1998) ; Martinez 2002) stated that aqueous extract of Azadirachta indica leaves and other Azadirachta indica based products have been extensively used in fish farms as alternative for the control of fish parasites and fish fry predators such as dragon fly larvae.

Although Azadirachta indica extract is considered of low toxicity toword non target aquatic life water extract of the bark of the neem plant caused respiratory problems in Tilapia zilli (Osmoregie and Okapanhchi, 1997) while long exposure to low concentration of the crude extract of Azadirachta indica delayed the growth of this Cichlid fish (Omoregie and Okapanchi, 1992)
The presents study investigates the effect of Azadirachta indica leaf extract on protein content of muscles and gills in semi fingerlings of Catla catla.

\section{Materials and Methods}

The semi fingerlings of Catla catla were procured from Manjrifish farm Hadapsar Pune in living condition weighting 1-1.55 gm. They were acclimatized to the laboratory condition for period of 15 days. Then all semi fingerlings, were divided into 10 batches in and each batch 10 semi fingerlings selected and were used for the present course of investigation. Whole experiment was carried out in Post Graduate Laboratory department of Zoology Poona College.

\section{Preparation of Aqueous Neem Leaf Extract}

Azadirachta indica leaves were collected from the surrounding area of the Pune City.The leaves were dried and finely chopped, then dissolved in tap water at concentration of $500 \mathrm{gm}$ of dried leaves per liter of water, for $24 \mathrm{hrs}$ at room temperature (Cruz et al., 2004). The mixture was filtered and the extract $(500 \mathrm{~g} / \mathrm{l})$ was used immediately in the experiment, in different dilutions.

\section{Fixation of sub leathal Concentration and Physiological Biological Assays}

Experiments was set to evaluate acute effect of leaf extract on protein. The semi fingerlings, were distributed in four groups and 4 fishes were kept in each group. It comprises two experimental group with control. Each group was placed into 1 lit of water. Experimental group were exposed for 2 days and 7 days to both concentration of leaf extract corresponding to sub lethal 
$\left(1 / 10^{\text {th }}\right.$ and 1/2). The control was simultaneously exposed to dechlorinated tap water and the end of $2^{\text {nd }}$ and $7^{\text {th }}$ day of exposure.

\section{Preparation of Tissue for Protein Estimation}

$100 \mathrm{mg}$ tissue of muscles and gills of Semi fingerling was taken into a Petri dish. $10 \mathrm{ml}$ of $10 \%$ TCA was added to it. After which the tissue was homogenized thoroughly. The tissue was centrifuged for $15 \mathrm{~min}$ at 3000 rpm.

Supernatant was discarded. The residual solution was diluted with $10 \mathrm{ml}$ of $1 \mathrm{~N}$ $\mathrm{NAOH}$. From this solution $0.1 \mathrm{ml}$ solution was taken in 3 different test tubes, in each test tube $4 \mathrm{ml}$ reagent ' $\mathrm{C}$ ' was added. After which $0.4 \mathrm{ml}$ of FCR was added. The solution was kept for $30 \mathrm{~min}$ at room temperature in dark condition.Optical density was taken at $540 \mathrm{~nm}$. Estimation of protein was done by (Lowry et. al 1951).

\section{Results and Discussion}

The finding of the present study clearly showed that the neem extract reduce the protein content of muscles and gills in semi fingerling of Catla catla.

In the present study Total protein $(\mathrm{mg} / \mathrm{dl})$ in muscles and gills decreased from 0.793 0.520 and $0.776-0.512$ for 2 days. When it was expose with concentration $4.25 \mathrm{mg} / \mathrm{lit}$ with $1 / 2 \quad 24 \mathrm{hrs}$ Lc50 respectively.Total protein $(\mathrm{mg} / \mathrm{dl})$ in muscles and gills decreased from $0.793-0.636$ and0.7760.586 for 2 days. When it was expose with concentration $0.85 \mathrm{mg} /$ lit with $1 / 10 \mathrm{th} 24 \mathrm{hrs}$ Lc50 respectively.

Total protein $(\mathrm{mg} / \mathrm{dl})$ in muscles and gills decreased from $0.793-0.504$ and $0.776-$ 0.495 for 7 days. When it was expose with concentration $4.25 \mathrm{mg} /$ lit with $1 / 2$ 24hrs Lc50 respectively. Total protein $(\mathrm{mg} / \mathrm{dl})$ in muscles and gills decreased from 0.793 0.628 and $0.776-0.578$ for 7 days. When it was expose with concentration $0.85 \mathrm{mg} /$ lit with 1/10th $24 \mathrm{hrs}$ Lc50 respectively. The overall results were represented in table 1.

Total protein $(\mathrm{mg} / \mathrm{dl})$ in muscles and gills decreased from $0.793-0.495$ and $0.776-$ 0.479 for 2 days. When it was expose with concentration $3.25 \mathrm{mg} /$ lit with $1 / 296 \mathrm{hrs} \mathrm{Lc}$ 100 respectively

Total protein $(\mathrm{mg} / \mathrm{dl})$ in muscles and gills decreased from $0.793-0.628$ and 0.7760.603 for 2 days. When it was expose with concentration $0.65 \mathrm{mg} /$ lit with $1 / 10$ th $96 \mathrm{hrs}$ Lc100 respectively.

Protein $(\mathrm{mg} / \mathrm{dl})$ in muscles and gills decreased from $0.793-0.471$ and $0.776-$ 0.462 for 7 days.

When it was expose with concentration $3.25 \mathrm{mg} /$ lit with $1 / 2$ 96hrs Lc 100 respectively.Total protein $(\mathrm{mg} / \mathrm{dl})$ in muscles and gills decreased from $0.793-$ 0.603 and $0.776-0.570$ for 7 days. When it was expose with concentration $0.85 \mathrm{mg} / \mathrm{lit}$ with 1/10th 96 hrs Lc100 respectively. The overall results were represented in table 2.

The finding of the present study showed that Azadirachta indica extract reduce the protein content of muscles and gills in semi fingerling of Catla catla.

The present finding correlates with report given by (Mamdouh A.A.mousa et al., 2008) showed the effect of Azadirachta indica leaf extract on fresh water fishes with respect to significant reduction in total protein content after treated Lc50 of Azadirachta indica leaf extract with non treated one after two and seven days of exposure were recorded. 
Table.1 Effect of Sub Lethal Concentration of Azadirachta indica Leaf Aqueous on Fingerlings of Catla catla for Different Period for Lc50 24 Hrs

\begin{tabular}{|c|c|c|c|}
\hline \multirow{2}{*}{$\begin{array}{c}\text { Concentration } \\
\text { (gm / lit })\end{array}$} & \multirow{2}{*}{$\begin{array}{c}\text { Parameter Period } \\
\text { (Days) }\end{array}$} & \multicolumn{2}{|c|}{ Total Protein(mg/dl) } \\
\hline & & Muscles & Gills \\
\hline Control & & 0.793 & 0.776 \\
\hline $\begin{array}{l}4.25 \text { conc. } \\
1 / 224 \text { hrs Lc50 }\end{array}$ & 2 & 0.520 & 0.512 \\
\hline $\begin{array}{l}0.85 \text { conc. } \\
1 / 10^{\text {th }} 24 \text { hrs Lc } 50\end{array}$ & & 0.636 & 0.586 \\
\hline $\begin{array}{l}4.25 \text { conc. } \\
1 / 224 \mathrm{hrs} \mathrm{Lc50}\end{array}$ & & 0.504 & 0.495 \\
\hline $\begin{array}{l}0.85 \text { conc. } \\
1 / 10^{\text {th }} 24 \mathrm{hrs} \mathrm{Lc50}\end{array}$ & 7 & 0.628 & 0.578 \\
\hline
\end{tabular}

Table.2 Effect of Sub Lethal Concentration of Azadirachta indica Leaf Aqueous on Semifingerlings of Catla catla for Different Period for Lc100 96 hrs

\begin{tabular}{|c|c|c|c|}
\hline \multirow{2}{*}{$\begin{array}{l}\text { Concentration } \\
\text { (gm / lit) }\end{array}$} & \multirow{2}{*}{$\begin{array}{c}\text { Parameter Period } \\
\text { (Days) }\end{array}$} & \multicolumn{2}{|c|}{ Total Protein(mg/dl) } \\
\hline & & Muscles & Gills \\
\hline Control & & 0.793 & 0.776 \\
\hline $\begin{array}{l}3.25 \text { conc. } \\
1 / 296 \text { hrs Lc100 }\end{array}$ & 2 & 0.495 & 0.479 \\
\hline $\begin{array}{l}0.65 \text { conc. } \\
1 / 10^{\text {th }} 96 \mathrm{hrs} \mathrm{Lc100}\end{array}$ & & 0.628 & 0.603 \\
\hline $\begin{array}{l}3.25 \text { conc. } \\
1 / 296 \text { hrs Lc100 }\end{array}$ & & 0.471 & 0.462 \\
\hline $\begin{array}{l}0.65 \text { conc. } \\
1 / 10^{\text {th }} 96 \text { hrs Lc100 }\end{array}$ & 7 & 0.603 & 0.570 \\
\hline
\end{tabular}

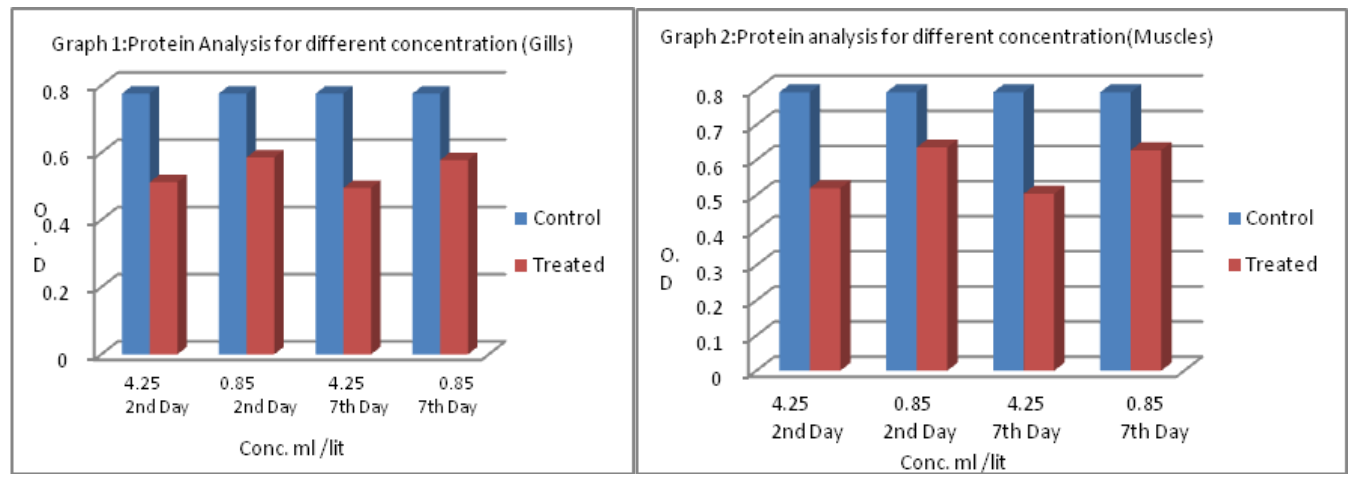




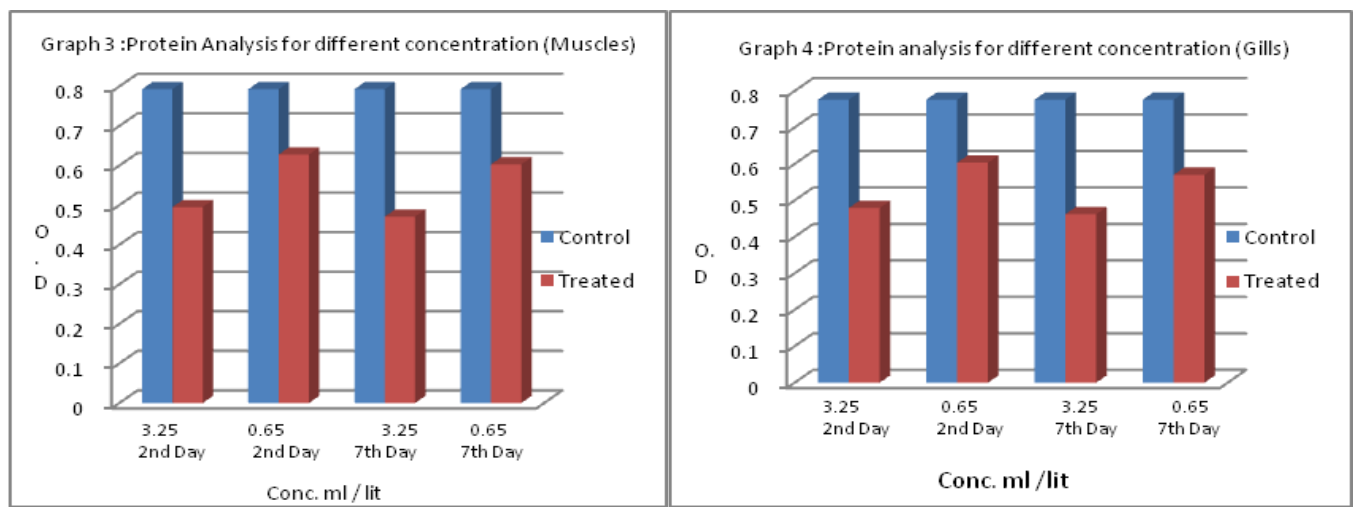

The similar finding reported from (Rathod S.H.et.al 2013) as the fishes were exposed to sub lethal conc. of Azadirachta indica (14 $\mu 1 /$ lit) for different time intervals. The total protein was found to decrease 50.40, 48.18,44.12 and 42.15 in muscles and 31.31, $29.60,27.21,25.14$ in liver tissue at the different exposure period and compare to control.

Similar finding by (Lynch et.al 1969) observed there is significant co relation between RNA and protein deficiency synthesis of a type of RNA should have in reflection in corresponding failure or reduction in protein synthesis. Tivari and Singer, (2006) reported that the decrease protein level in liver and muscles of fish exposed to Azadirachta indica extract might have a resulted from high protein hydrolytic activity in both the tissue.

In the present report the decrease of protein level in muscles and gills during sub lethal exposure might have resulted from their degradation and possible utilization from metabolic purpose.

The present study indicates that leaf extract of Azadirachta indica has caused significant alternation in protein content of muscles and gills in semi fingerling of Catla catla which might be helpful to management and the better usage of aqueous extract of Azadirachta indica in aquaculture farms.

\section{Acknowledgement}

The authors would like to acknowledge to Head, Department of Zoology, Poona College for providing necessary facilities during course of work.

\section{References}

Barton, B.A., G.K.Iwama 1991. Physiological changes in fish from stress in aquaculture with emphasis on the response and effect of corticosteroid.Annu.Rev.Fish Dis.1:326

Biswas, K.I. Chattopadhyay, R.K.Banerjee, and U.Bandyopadhayay.2002. Biological activities and medicinal properties of neem (Azadirachta indica) Curr.Sci.82:1336-1345

Cruz, C., J.G. Machado-Neto and M.L. Menezes 2004.Toxicidadeaguda do insecticida Paratinmetilico e do biopecticida azadiractina de folhas de neem (Azadirachta indica)paraalevino e juvenile de pacu (Piaractusme sopotamicus) pesticidas :R Ectoxicol. eMeio Ambiente 14:92-102.

Dunkel,F.V.,D.C.Ricilards.1998. Effect of an azazdirachtin formulstion on six non target aquatic macro invertebrates, Environ.Entomol.27:667-673.

Harikrishanan, R.,M.N.Rani and C.Balsundram. 2003. Hematological and biochemical parameter in common 
carp,Cyprinuscarpio,following herbal treatment for Aeromonashydraphila infection.aquaculture 221:41-50

ICAR.1993.World Neem conference souvenir ICAR, Bangalore,India

Lowry,O.H.,Rosebrough,N.J.,Fiir,A.L.,andR andall,R.J(1951).J.Biol.Chem., 193.265

Martinez,,S.O.2002. NIM-AzadirahtaIndica :natureza, usomultiploseproo Instituto Agr Onomicodo Parana (IAPAR), Londrina, PR.

Omoregie, E.,M.A.Okpanachi.1992. Growth of Tilapia zilli exposed to sublethal concentration of crude extract of Azadirachta indica. Actahydrobiol., 34:281-286

Senhorini J.A.1991.Larviculture do pacu Piaractus mesopotamicus Holmberg. 1887. (Pisces Characidae) emviveiros com esemorganofosforados (Folidol 60\%) Boletim Tecnicodo CEPTA 4, 11-22.

Siwicki, A.K., D.P. Anderson and G.L. Rumsey (1994). Dietary intake of immunostimulants by rainbow trout affects non-specific immunity and protection against furunculosis. Vet. Immunopathol.41:125-139.
Tiwari,S. and singh,A.2006. Biochemical stress response in fresh water fish channapunctatus induced by aqueous extract of Euphorbia tirucalli plant.Chemosphere,64:36-42

Rathod, S.H.2013. Effect of Azadirachtaindica on the total protein of the fresh water cat fish Heteropneustes fossilis. Int.journal of Innovation in Bio-Sciences. Vol 3(2): 64-67.

Lynch,M.J., S.S.Raphael, L.D. Mellor, P.D. Spase and M.J.H. In wood. Medical laboratory Technology and clinical pathology, $\quad 2^{\text {nd }} E d . W . B . \quad$ Saunders Co.Toronto, London.

Van Der Nat,M.G.,KTD.Van Der Sluis \& R.P. Labadie. 1991. Ethnophormocognostical survey of A. indicajuss (Maliaceae). J Ethnopharacol., 35:1-24

Wan. M.T., R.G.Watts, M.B.Isman and R.Strub.1996. Evaluation of the acute toxicity to juvenile pacific northeast salmon of azadirachtin, neem extract and neem based product. Bull.Enviorn. Contam.Toxicol., 56:432-439.

\section{How to cite this article:}

Rukhsar Shaikh, M.A.Majid and KalimShaikh. 2016. Effect of Azadirachta indica Leaf extract on protein content in muscles and gills of semi fingerling of Catla catla. Int.J.Curr.Microbiol.App.Sci.5(2): 701-706. doi: http://dx.doi.org/10.20546/ijcmas.2016.502.077 